FITRAH Jurnal Kajian Ilmu-ilmu Keislaman

Vol. 04 No. 2 Desember 2018

e-ISSN : 2460-2345, p-ISSN: 2442-6997

Web: jurnal.iain-padangsidimpuan.ac.id/index.php/F

\title{
PENERAPAN HUKUMAN TA'ZIR DI INDONESIA (Suatu Analisis Terhadap Penerapan Hukuman di Lapas Kota Padangsidimpuan)
}

\author{
HENDRA GUNAWAN \\ IAIN Padangsidimpuan \\ hendragunawan@iain-padangsidimpuan.ac.id
}

\begin{abstract}
This study aims to reveal the application of ta'zir penalty in Indonesia by analyzing the application of penalty in Padangsidimpuan class II B prison, this research is a type of field research with a qualitative approach that the data have been collected by using observation and interview techniques, and data analysis techniques used a comparative model. The results of the analysis show that in prison class II B Padangsidimpuan there are three types of crimes which are crimes of ta'zir or new types of crimes that have not been clearly stated in the Koran regarding the penalty of narcotics, corruption, and penalty for child offenders. Where all the perpetrators were sentenced to ta'zir or penalty based on a judge's decision, from the practice of applying penalty in class II B prison Padangsidimpuan shows that indirectly the terminology of ta'zir penalty in the Islamic criminal law realm has actually been applied in Indonesia, namely correctional institutions.
\end{abstract}

Keywords: application, penalty, and ta'zir,

\begin{abstract}
Abstrak
Penelitian ini bertujuan untuk mengungkap penerapan hukuman ta'zir di Indonesia dengan menganalisis penerapan hukuman di penjara kelas II B Padangsidimpuan, penelitian ini merupakan jenis penelitian lapangan dengan pendekatan kualitatif untuk analisis komparatif. Sedangkan pengumpulan data dalam penelitian ini dilakukan melalui teknik observasi dan wawancara, sedangkan teknik analisis data menggunakan model komparatif. Hasil analisis menunjukkan bahwa di Lapas kelas II B Padangsidimpuan ada tiga jenis kejahatan yaitu kejahatan ta'zir atau jenis kejahatan baru yang belum dinyatakan secara jelas dalam Alquran mengenai hukuman terhadap narkotika, korupsi, dan hukuman. untuk pelanggar anak. Dimana semua pelaku dijatuhi hukuman ta'zir atau hukuman berdasarkan keputusan hakim, dari praktek menerapkan hukuman di kelas II B penjara Padangsidimpuan menunjukkan bahwa secara tidak langsung terminologi hukuman ta'zir di ranah hukum pidana Islam sebenarnya telah diterapkan di Indonesia, yaitu lembaga pemasyarakatan.
\end{abstract}

Kata Kunci: Penerapan, Hukuman, dan Ta'zir. 
FITRAH Jurnal Kajian Ilmu-ilmu Keislaman

Vol. 04 No. 2 Desember 2018

\section{PENDAHULUAN}

Pada hakikatnya, perilaku seorang insan manusia didorong oleh keinginan untuk memenuhi berbagai kebutuhan baik kebutuhan diri, keluarga, maupun kelompok sehingga untuk meraih itu semua banyak yang melakukan jarimah (kejahatan) seperti mencuri supaya cepat kaya raya, semakin banyak kebutuhan seseorang maka semakin kuat pula dorongan untuk melakukan berbagai kejahatan. Dengan kata lain, kejahatan bukanlah produk alam melainkan produk manusia sehingga untuk mencegahnya perlu diberikan hukuman agar tidak melakukannya kembali. Dalam al-Qur'an, Allah SWT telah menjelaskan berbagai macam bentuk kejahatan lengkap beserta hukumannya mulai dari kejahatan perzinaan, pencurian, perampokan, dan sampai kepada kejahatan pembunuhan yang dihukum dengan qishash (hukuman setimpal), semua kejahatan ini menurut Ahmad Wardi Muslich ${ }^{1}$ merupakan hak Allah SWT sehingga dijelaskan dengan tegas dalam al-Qur'an dan pakar hukum pidana Islam menamai kejahatan tersebut jarimah hudud yaitu jenis-jenis kejahatan atau hukuman yang telah ditetapkan oleh Allah SWT.

Namun, yang menjadi persoalan dikarenakan sifat manusia yang dinamis membuat model kejahatan pun semakin bervariatif, berkembang, dan kompleks dari masa ke masa seperti narkotika dan korupsi yang hukumannya pun secara tegas tidak ditemukan dalam al-Qur'an. Maka untuk menuntaskan persoalan ini, hukum Islam telah menawarkan term ta'zir yaitu suatu istilah untuk jenis kejahatan ataupun hukuman yang belum ditetapkan Allah SWT secara tegas, dimana dalam term ta'zir ini memberikan kesempatan yang luas kepada ulil amri (penguasa, pemimpin, atau hakim) untuk menetapkan hukuman terhadap kejahatan-kejahatan yang baru guna menjaga ketertiban umum.

Tujuan penelitian ini, untuk memperoleh gambaran yang objektif dan konprehensif tentang penerapan hukuman ta'zir di lapas kelas II B Padangsidimpuan diantaranya dilihat dari program-program lapas kelas II B Padangsidimpuan, konsep hukuman ta'zir penjara dalam hukum pidana Islam, serta perbedaan dan kesamaan konsep lapas kelas II B Padangsidimpuan dengan

\footnotetext{
${ }^{1}$ H. Ahmad Wardi Muslich, Pengantar Dan Asas Hukum Pidana Islam: Fikih Jinayah (Jakarta: $\begin{array}{llllll}\text { Sinar } \quad \text { Grafika, 2004), } & 7 & \text { hlm. } & \text { 254, }\end{array}$ https://books.google.co.id/books?id=rqedAQAACAAJ\&dq=Ahmad+Wardi+Muslich,+Pengantar+da n+Asas+Hukum+Pidana+Islam;+Fiqh+Jinayah\&hl=en\&sa=X\&ved=0ahUKEwjJqK_3g87fAhUMknA KHVlADDwQ6AEIKTAA.
} 
konsep hukuman ta'zir penjaradalam perspektif hukum pidana Islam. Dengan penelitian ini, diharapkan dapat bermanfaat sebagai indikator awal untuk mengukur penerapan hukum pidanaIslam di Indonesia, sebagai wadah untuk memperkenalkan term ta'ziryang sudah ada di lembaga pemasyarakatan, dan sebagai referensi untuk memperkayasilabus materi kuliah jurusan Hukum Pidana Islam (HPI) fakultas Syariah dan Ilmu Hukum IAIN Padangsidimpuan.

\section{KAJIAN TEORI}

Abdul al-Qadir 'Audah, menyebutkanbahwata'zir merupakan jenis hukuman yang dijatuhkan kepada pelaku jarimah $t a^{\prime} z i{ }^{2}$ (jenis kejahatan yang tidak dijelaskan secara tegas dalam al-Qur'an) termasuk terhadap kejahatan yang telah ditegaskan Allah SWT dalam al-Qur'an namun mengenai hukumannya tidak dijelaskan secara terperinci tentang hukumannya terutama terhadap jarimah $\mathrm{ta}^{\prime}$ zir (kejahatan baru) seperti narkotika dan korupsi. Mengenai hukuman ta'zir, diserakan kepada hakim untuk menetapkan hukumannya bisa saja menjatuhkan hukuman berupa peringatan, teguran, denda, pukulan, penjara, dan lain sebagainya tergantung berat dan ringannya pelanggaran atau kejahatan yang dilakukannya sebab hukuman ta'zir sifatnya pembelajaran. Bahkan Rahmat Hakim menuliskan, bahwa khusus anak yang belum baligh (dewasa) hanya dikenakan hukuman $t a^{\prime} z i r$ (hukuman berupa pembinaan) ${ }^{3}$ apabila melakukan kejahatan, lebih dari itu Ridho Rokamah ${ }^{4}$ menuturkan bahwa hukum hudud sendiri pun bisa gugur sehingga diganti dengan hukuman ta'zir karena terdapat unsur syubhat (ketidak jelasan) seperti kasus perzinaan yang tidak ditemukan bukti yang akurat sebagaimana Rasulullah SAW pernah menyeru meninggalkan hukuman hadkarena syubhat (samar-samar), yang kemudian di tegaskan Rasulullah SAWsesungguhnya imam (penguasa) sekiranya salah dalam memberikan maaf adalah lebih baik daripada dalam rangka memberikan hukuman.

Hukuman ta'zir,sangat berkaitan dengan akal manusia karena di sini sangat melibatkan penilaian kemanusiaan sebagaimana terlihat dalam al-Qur'an hlm. 128.

${ }^{2}$ Abd al-Qadir 'Audah, Al-Tasyri' al-Janaiy al-Islamy (Beirut: Muassasah al-Risalah, 1992),

${ }^{3}$ Rahmat Hakim, Hukum Pidana Islam: Fiqh Jinayah (Bandung: Paustaka Setia, 2000), hlm. 177.

${ }^{4}$ Ridho Rokamah, Al-Qawa'id Al-Fiqhiyah: Kaidah-Kaidah Mengembangkan Hukum Islam (Ponorogo: STAIN Ponorogo Press, 2007), hlm. 68-69. 
FITRAH Jurnal Kajian Ilmu-ilmu Keislaman

Vol. 04 No. 2 Desember 2018

surah shaad ayat 26 yang berbunyi "Hai Dawud, sesungguhnya kami menjadikan kamu khalifah (penguasa) di muka bumi, maka berilah keputusan (perkara) diantara manusia dengan adil dan janganlah kamu mengikuti hawa nafsu, karena ia akan menyesatkan kamu dari jalan Allah SWT., sesungguhnya orang-orang yang sesat darin jalan Allah SWT akan mendapat azab yang berat karena mereka melupakan hari perhitungan". Ini menunjukkan, bahwa Allah SWT memberikan rekomendasi kepada nabi Dawud AS supaya memutuskan suatu perkara dengan mengedepankan keadilan sehingga dari sini dapat disimpulkan bahwa akal manusia memiliki otoritas dalam memutuskan sebuah perkara yang belum ada ketegasannya dalam al-Qur'an maupun sunnah Rasulullah SAW dengan catatan bahwa keputusan itu harus mengedepankan keadilan termasuk menetapkan hukuman terhadap persoalan kontemporer atau kejahatan baru.

Beranjak dari teori-teori di atas, yang menerangkan bahwa hukuman ta'zir merupakan produk manusia yang berdasarkan kemaslahatan yang dijatuhkan oleh hakim terhadap kasus atau kejaharan yang kontemporer, maka dari sini penulis mencoba menganalisis eksistensi penerapan hukuman ta'zir di Indonesia khususnya di lapas kota Padangsidimpuan.

\section{METODE PENELITIAN}

Penelitian ini dilaksanakan di lembaga pemasyarakatan kelas II B Padangsidimpuan, yang beralamat di desa Salambue kecamatan Padangsidimpuan Tenggara kota Padangsidimpuan provinsi Sumatera Utara, pada bulan Maret sampai bulan Agustus tahun 2018. Penelitian ini merupakan penelitian lapangan dengan pendekatan kualitatif analisis komparatif, dimana pengambilan data penelitian ini dilakukan secara alami dan natural dari subjek penelitian yaitu petugas penyelenggara, petugas pembina, dan narapidanalapaskelas II B Padangsidimpuan. Teknik pengumpulan data dalam penelitian ini, dilakukan melalui observasi, interview, dan dokumentasi. Keabsaan data penelitian ini, dilakukan dengan cara memperpajang masa penelitian, mengamati secara terus-menerus, melakun triangulasi data mealui rechecking dan crosschecking serta membicarakannya langsungdengan penyelenggara lapas kelas II B Padangsidimpuan. 
Selanjutnya, data dianalisis menggunakan model analisis kompratif, yaitu suatu analisis perbandingan untuk menemukan persamaan dan perbedaan yang dalam penelitian ini mencoba mencari kesamaan dan perbedaan penerapan hukuman di lapas kelas II B Padangsidimpuan dengan terminologi ta'zir dalam hukum pidana Islam.

\section{HASIL PENELITIAN DAN PEMBAHASAN}

\section{Program Lapas Kelas II B Padangsidimpuan}

Dari data-data yang diproleh di lapangan, bahwa lapas kelas II B Padangsidimpuan memiliki program yang terencana, sistematis, dan terpadu dengan melibatkan berbagai instansi karena lapas kelas II B Padangsidimpuanmerupakanlembaga pemasyarakatan di wilayah Kementerian Hukum dan Hak Asasi Manusia (Kemenkumham) yang berfungsi untuk menampung, merawat, dan membina narapidana dari seluruh wilayah kota Padangsidimpuan sebagaimana telah diamanahkan undang-undang nomor 12 tahun 1995 tentang pemsyarakatan pada pasal 1 ayat 1 dan 3 sebagai berikut :5 Pasal 1 ayat 1 ;

"Pemasyarakatan adalah kegiatan untuk melakukan pembinaan warga binaan pemasyarakatan berdasarkan sistem, kelembagaan, dan cara pembinaan yang merupakan bagian akhir dari sistem pembinaan dalam tata peradilan pidana". Pasal 1 ayat 2 ;

"Sistem pemasyarakatan adalah suatu tatanan mengenai arah dan batas serta cara pembinaan warga binaan pemasyarakatan berdasarkan pancasila yang dilaksanakan secara terpadu antara Pembina, yang dibina, dan masyarakat untuk meningkatkan kualitas warga binaan pemasyarakatan agar menyadari kesalahan, memperbaiki diri, dan tidak mengulangi tindak pidana sehingga dapat diterima kembali oleh lingkungan masyarakat, dapat aktif berperan dalam pembangunan, dan dapat hidup secara wajar sebagai warga yang baik danbertanggung jawab".

\section{Pasal 1 ayat 3 ;}

“Lembaga Pemasyarakatan yang selanjutnya disebut lapas adalah tempat untuk melaksanakan pembinaan narapidana dan anak didik pemasyarakatan".

5Undang-Undang Nomor 12 Tahun 1995 Tentang Pemasyarakatan. 
FITRAH Jurnal Kajian Ilmu-ilmu Keislaman

Vol. 04 No. 2 Desember 2018

Terkait pembinaan nara pidana, menurut Elfrida Harahap 6 dan Efrida Sri Mulyana $^{7}$ di lapas kelas II B Padangsidimpuan terdapat 3 (tiga) bidang pembinaan yaitu pembinaan mental (kepribadian), keterampilan, dan kemandirian.Pertama, program pembinaan kepribadianyaitu menanamkan kesadaran beragama, berbangsa, dan bernegara serta mempertajam kecerdasan intelektual agar para napi dapat berintegrasi dengan baik di masyarakat danmemiliki kesadaran berhukum. Kedua, pembinaan meningkatkan keterampilan mulai keterampilan bidang olahraga dan kesenian sampai kepada keterampilan bidang kewirausahaan seperti pelatihankerajinan tangan, tenun, pertukangan, pertanian, dan lainnya. Ketiga, program kemandirian yang menurut Ryan Ya'cub Azhari ${ }^{8}$ dan Andika Pahlevi ${ }^{9}$ para napi diberikan kesempatanatudilatih untuk mandiri dengan berkebun dan berbudi daya ikan di lingkungan lapas kelas II B Padangsidimpuan.

Untuk meningkatkan kehidupan beragama warga binaan, lapas kelas II B Padangsidimpuan melaksanakan berbagai program pembinaan keagamaan yang terintegrasi di Masjid Al-Ikhlas lapas kelas II B Padangsidimpuan, sebagaimana menurut BKM Masjid Al-Ikhlas lapas kelas II B Padangsidimpuan bahwa di masjid Al-Ikhlas banyak terdapat kegiatan keagamaan sebagai berikut : ${ }^{10}$

\begin{tabular}{|c|c|c|c|}
\hline No & UraianKegiatan & Agenda & Keterangan \\
\hline 1 & Ceramah agama & Mingguan & $\begin{array}{l}\text { Setiap hari Jum'at sebelum } \\
\text { shalat Jum'at. }\end{array}$ \\
\hline 2 & Tadarusal-Qur'an & Harian & $\begin{array}{l}\text { Setiap malam sesudah shalat } \\
\text { Magrib }\end{array}$ \\
\hline 3 & Belajar ilmu tajuwid & Mingguan & $\begin{array}{l}\text { Setiap malam Minggu setelah } \\
\text { Magrib }\end{array}$ \\
\hline 4 & $\begin{array}{l}\text { Pelatihan } \\
\text { jenazah }\end{array}$ & Mingguan & $\begin{array}{l}\text { Setiap malam Jum'at setelah } \\
\text { Magrib }\end{array}$ \\
\hline 5 & Pelatihan khutbah & Mingguan & Setiap hari Jum'at. \\
\hline 6 & $\begin{array}{l}\text { Pelatihan marjanji dan } \\
\text { rabana }\end{array}$ & Mingguan & $\begin{array}{l}\text { Setiap menyambut hari-hari } \\
\text { besar }\end{array}$ \\
\hline 7 & Pelatihan & Mingguan & Sekali sebulan \\
\hline
\end{tabular}

${ }^{6}$ Wawancara dengan Eferida Harahap, S.H selaku Bendahara Pengeluaran Lembaga Pemasysrakatan Kelas II B Padangsidimpuan pada Kamis tanggal 21 Juni 2018.

${ }^{7}$ Wawancara dengan ibu Efrida Sri Mulyana, S.H selaku Kasi Binadik/ Giatja Lembaga Pemasyarakatan Kelas II B Padangsidimpuan, pada hari Rabu tanggal 4 Juli 2018.

${ }^{8}$ Wawancara dengan Bapak Ryan Ya'cub Azhari selaku anggota jaga Lembaga Pemasyarakatan Kelas II B Padangsidimpuan, pada hari Jum'at tanggal 20 Juli 2018.

${ }^{9}$ Wawancara dengan Bapak Andika Pahlevi, S.H selaku Karupam Lembaga Pemasyarakatan Kelas II B Padangsidimpuan, pada hari Rabu tanggal 18 Juli 2018.

${ }^{10}$ Wawancara dengan Bapak Drs. H. Asgul Dalimunthe, M.Si selaku BKM Mesjid Al-Ikhlas Lembaga Pemasyarakatan Kelas IIB Padangsidimpuan, pada hari Jum'at tanggal 20 Juli 2018. 
Menurut Ali Basya ${ }^{11}$ bahwa utuk membenahi spiritual narapidaa lapas kelas II B Padangsidimpuan maka pihak lapas sering menghadirkan da`i kondang lokal ke lapas kelas II B Padangsidimpuan pada setiap acara-acara keagamaan seperti pengajian akbar, dan isra' mi'raj untuk meningkatkan wawasan religi para narapidana khususnya yang beragama Islam, terutama narapidana yang masih tergolong sangat muda dan narapidana anak untuk melindungi dan mengayomi masa depan mereka yang masih panjang agar kelak nantinya mereka menjadi manusia yang bertanggungjawab dan berguna bagi masyarakat, bangsa, dan negara sebagaimana diamanatkan juga dipertegas oleh undangundang nomor 3 tahun 1997 tentang pengadilan anak. ${ }^{12}$

Permasalahan sekarang, adalah, apakah program-program lapas kelas II B Padangsidimpuan ini memiliki kesamaan atau perbedaan dengan program penjara yang terdapat dalam hukum pidana Islam?, yang apabila ditelusuri dalam sejarah peradaban Islam tercatat bahwa program pembinaan napi yang dipraktekkan di lapas kelas II B Padangsidimpuan sudah ada dalam sejarah peradaban Islam, dimana para tahanan perang yang memiliki keterampilan seperti memiliki keterampilan membaca dan menulis maka yang bersangkutan akan diminta pemerintah untuk mengajarkannya kepada yang lain, begitu juga halnya dengan orang-orang yang memiliki keahlian khusus akan diminta supaya diajarkan dan dikembangkan buat masyarakat umum.

\section{Lembaga Pemasyarakatan dalam Sejarah Hukum Pidana Islam}

Di dalam hukum pidana Islam, lembaga pemasyarakatan atau penjara dikenal dengan al-habsu yang secara etimologinya berarti menahan sedangkan secara terminologi adalah mencegah pelaku kejahatan dari bergaul dengan masyarakat. Menurut Ahmad Wardi Muslich, ${ }^{13}$ bahwa hukuman ta'zir penjara dalam hukum pidana Islam ${ }^{14}$ pernah diterapkan terhadap pelaku kejahatan penghinaan, penjual khamar, pemakan riba, dan melanggar kehormatan bulan

\footnotetext{
${ }^{11}$ Wawancara dengan Bapak Ali Basya, S.H selaku Kaur Kepegawaian \& Keuangan Lembaga Pemasyarakatan Kelas IIB Padangsidimpuan, pada hari Rabu tanggal 18 Juli 2018.

${ }^{12}$ Lihat Undang-UndangNomor 3 Tahun 1997 TentangPengadilanAnak.

${ }^{13}$ Muslich, Pengantar Dan Asas Hukum Pidana Islam, hlm. 262-263.

${ }^{14}$ Hukum pidana Islam ialah seperangkat norma atau peraturan yang bersumber dari Allah SWT dan Rasulullah SAW tentang kejahatan, pelanggaran-pelanggaran, dan hukumannya untuk mengatur insan manusia dalam bermasyarakat yang dalam literatur fikih klasik biasanya disebut jinayah A. DJazuli, Figh Jinayah; Upaya Menanggulangi Kejahatan dalam Islam, cet ke-3 (Jakarta: Rajawali Pers, 2000), hlm. 2.
} 
FITRAH Jurnal Kajian Ilmu-ilmu Keislaman

Vol. 04 No. 2 Desember 2018

suci Ramadhan dimana para pelaku dipenjara sampai waktu yang telah ditentukan, sampai ia bertaubat, dan bisa saja seumur hidup seperti yang terdapat dalam Kitab Undang-undang Hukum Pidana ${ }^{15}$ (KUHP) buat pelaku kejahatan yang sangat berbahaya.Namun penampilan penjara dulu, berbeda dengan lembaga pemasyarakatan (Lapas) sekarang ini dimana lapas sekarang berbentuk sebuah bangunan dengan pagar menjulang serta pintu dan jendela yang terbuat dari besi sedangkan pada masa Rasulullah SAW penjara tidak berbentuk khusus dimana pelaku kejahatan hanya diikat di pagar, mesjid, dan atau di rumah sebagaimana dicantumkan dalam al-Qur'an surah an-Nisa ayat 15 sebagai berikut :

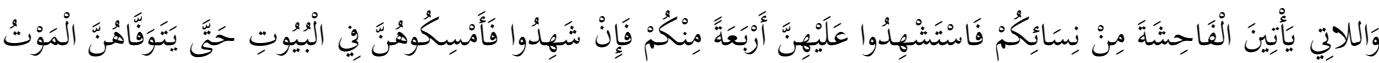

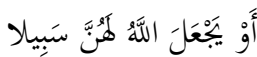

Artinya :

“Dan para perempuan yang melakukan perbuatan keji di antara perempuanperempuan kamu, hendaklah terhadap mereka ada empat orang saksi di antara kamu (yang menyaksikannya), apabila mereka telah memberi persaksian, maka kurunglah mereka (perempuan itu) dalam rumah sampai mereka menemui ajalnya, atau sampai Allah memberi (jalan yang lain) kepadanya. \{Qs. An-Nisa'/4:15\}. ${ }^{16}$

Ayat di atas, menunjukkan perintah menahan atau memenjarakan dalam rumah karena memang pada masa Rasulullah SAW sampai kepada masa khalifah Abu Bakar belum ada tempat khusus yang disediakan untuk memenjarahkan pelaku kejahatan. Akan tetapi, setelah umat Islam bertambah banyak dan wilayah kekuasaan Islam pun sudah bertambah luas Abu Bakar pun membeli rumah Shafwan ibn Umayyah dengan harga 4.000 dirham yang kemudian dijadikannya sebagai penjara dan tercatat sebagai penjara pertama dalam Islam yang terletak di Makkah yang selanjutnya pada masa kahlifah Ali bin Abi Thalib pun membangun penjara yang diberikan nama Mukhayyis.Terlepas dari historis tetang bangunan penjara perdana dalam Islam ini, sebenarnya jauh hari sebelumnya yaitu pada masa nabi Yusuf AS istilah penjara telah ada sebagaimana diterangkan dalam al-Qur'an surah Yusuf ayat 33 dan 42 yang berbunyi sebagai berikut :

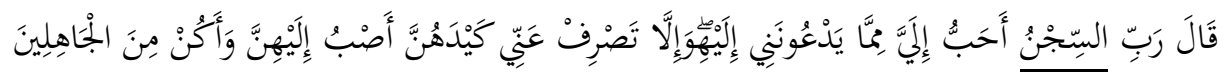

${ }^{15}$ Moeljatno, KUHP; Kitab Undang-Undang Hukum Pidana, edisi baru (Jakarta: PT. Bumi Aksara, 2008).

16 Departemen Agama Republik Indonesia, Al-Qur'an Al-Karim dan Terjemahannya (Semarang: PT. Karya Toha Putra, 2002), hlm. 103-104. 
Artinya: "Yusuf berkata;'Wahai Tuhanku! penjara lebih aku sukai daripada memenuhi ajakan mereka. Jika aku tidak Engkau hindarkan dari tipu daya mereka, niscaya aku akan cenderung untuk (memenuhi keinginan mereka) dan tentu aku termasuk orang yang bodoh." $\{\mathrm{Q}$. Yusuf/12: 33\}17

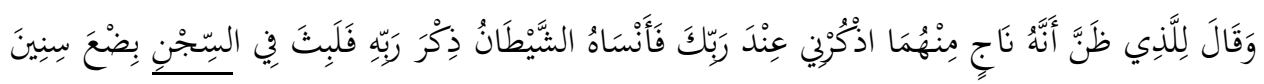

Artinya: "Dan dia (Yusuf) berkata kepada orang yang diketahuinya akan selamat di antara mereka berdua;'Terangkanlah keadaan ku kepada tuanmu'. Maka setan menjadikan dia lupa untuk menerangkan (keadaan Yusuf) kepada tuannya.Karena itu dia (Yusuf) tetap dalam penjara beberapa tahun lamanya." $\{Q s$. Yusuf/12: 42$\} .{ }^{18}$

Menurut Abd al-Qadir 'Audah, ${ }^{19}$ pada prinsipnya suatu hukuman, harus dilegalisir (diabsahkan) oleh perundang-undangan dikenal dengan asas legalitas yang merupakan asas mutlak dipakai dalam penerapan hukum sebab tanpa adanya praturan-perundang-undangan seseorang tidak dapat dipidana atau dihukum. Maka menurut Zul Anwar Ajim, ${ }^{20}$ bahwa peraturan perundangundangan dalam hukum Islam adalah ketentuan yang telah ditetapkan Allah SWT sehingga kedua ayat di atas dan surah an-Nisa' ayat 15 di atas dapat dikategorikan sebagai asas legalitas penerapan hukuman ta'zir penjara.

Selain itu, menurut Makhrus Munajat ${ }^{21}$ bahwa hukuman pengasingan atau mengisolir pelaku kejahatan dari masyarakat yang terdapat dalam hukum pidana Islam klasik sudah kurang relevan dengan kondisi sekarang ini mengingat transportasi yang terus mengalami kemajuan sehingga hukuman pengasingan akan kurang efektif sebab pelaku dengan mudah berpindahpindah, maka banyak ulama kontemporer yang mengedepankan esensi pengasingan itu sebagai pemisahan pelaku dari masyarakat sama dengan penjara yaitu sama-sama bertujuan mengasingkan pelaku tersebut dari masyarakat luas sebagai upaya perbaikan atau pendidikan terhadap pelaku supaya bertaubat (insaf) atau menyadari kesalahanya sehingga ia dapat menjadi

${ }^{17}$ Departemen Agama Republik Indonesia, Al-Qur'an Al-Karim .., hlm. 322.

${ }^{18}$ Departemen Agama Republik Indonesia, Al-Qur'an Al-Karim .., hlm. 323.

${ }^{19}$ Abd al-Qadir 'Audah, Al-Tasyri' al-Janaiy al-Islamy, hlm. 113.

20 Zul Anwar Ajim Harahap, "Azas Legalitas dalam Hukum Pidana Islam,” $A L-$ MAQASID: Jurnal Ilmu Kesyariahan dan Keperdataan 2, no. 1 (Juni 2016): hlm. 180.

${ }^{21}$ Makhrus Munajat, Hukum Pidana Islam di Indonesia (Yogyakarta: Teras, 2009), hlm. 177181. 
FITRAH Jurnal Kajian Ilmu-ilmu Keislaman

Vol. 04 No. 2 Desember 2018

insan yang baik serta bertakwa kepada Allah SWT, karena sebuah hukuman dapat dikatakan berhasil apabila dapat memberikan kesadaran terhadap diri pelaku yang kemudian berusaha tidak melakukannya karena takut akan hukuman serta keinginan menggapai keridhaan Allah SWT.

Persamaan dan Perbedaan Konsep Ta'zir dan Penerapan hukuman di Lapas Kota Padangsidimpuan

Berdasarkan data di atas, bahwa kasus yang terdapat di lapas kelas II B Padangsidimpuan dapat dipisahkan kedalam kategori jarimah ta'zir dengan klasifikasi berdasarkan Kejahatan Ta'zir (KT) dan Kejahatan Bukan Ta'zir (KBT) sebagai berikut ;

Fokus penelitian adalah pada kejahatan ta'zir (KT) yaitu kejahatan narkotika dan korupsi yang masing-masing dikenai hukuman yang berbedabeda sekalipun pasal kejahatannya sama sebagai berikut :

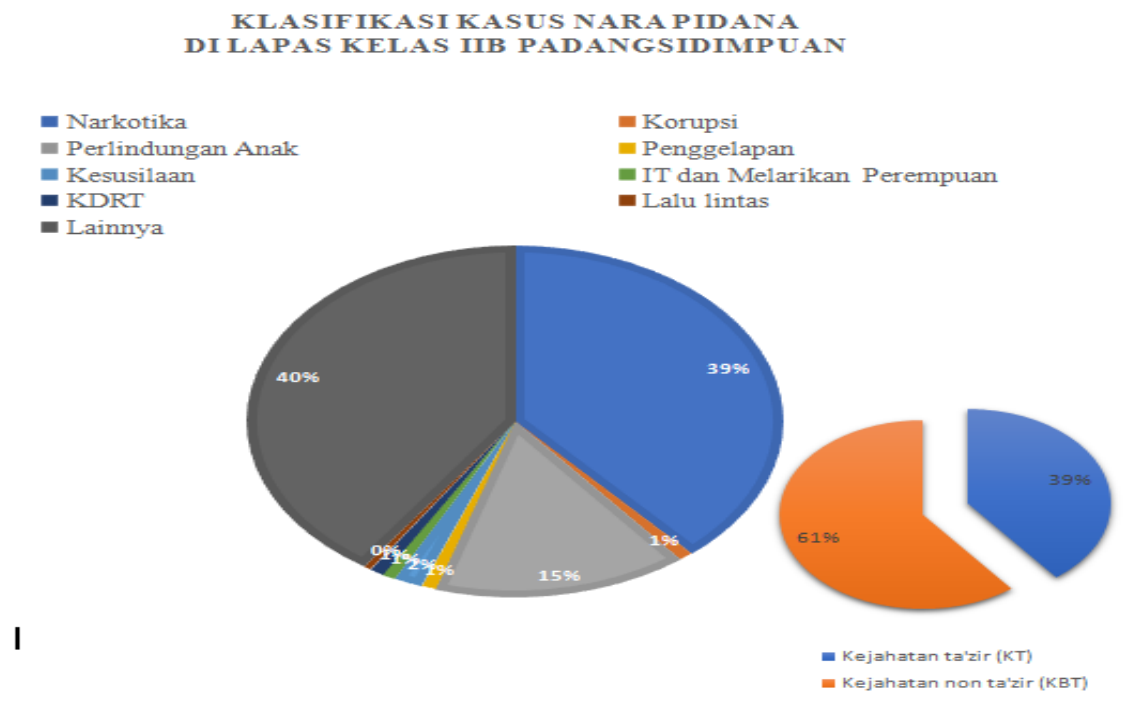

Dari data yang diperoleh bapak Muslihul Hayat Harahap ${ }^{22}$ selaku Kasubsi Registrasi \& Bimkemas Lembaga Pemasyarakatan Kelas IIB Padangsidimpuan ini, terlihat bahwa hukuman yang paling rendah pada jarimah ta'zir yaitu kasus narkotika, korupsi, dan pelaku kejahatan anak di lapas kelas II B Padangsidimpuan adalah dimulai hukuman penjara 10 (sepuluh) bulan sampai

${ }^{22}$ Wawancara dengan Bapak Muslihul Hayat Harahap, Amd., SE selaku Kasubsi Registrasi \& BimkemasLembaga Pemasyarakatan Kelas IIB Padangsidimpuan, pada hari Rabu tanggal 11 Juli 2018. 
kepada hukuman yang paling berat yaitu hukuman penjara 18 tahun. Tiga macam jenis hukuman ta'zir di lapas kelas II B Padangsidimpuan yang terdiri dari kejahatan narkotika, korupsi, dan pelaku kejahatan anak. Penelitian yang dilakukan oleh Endang Jumali juga menyatakan terdapat kenungkinan pelaksanaan hukum $\mathrm{Ta}^{\prime}$ zir bagi pelaku korupsi ${ }^{23}$. Hal ini dilakukan dalam rangka menyahuti penegakan hukum di Indonesia.

Narkotika dikategorikan kedalam jarimah ta'zir, sebab kejahatan narkotika merupakan jenis kejahatan yang baru ada di zaman kontemporer karena term narkotika tidak ada termaktub secara tekstual dan eksplisit di dalam al-Qur'an maka hukumannya pun adalah ta'zir (sesuai dengan keputusan pemerintah atau hakim), sedangkan kasus korupsi oleh sebagian pakar juga mengategorikannya bukan kepada tindakan kejahatan sariqah (pencurian) melainkan dikategorikan kepada pengkhianatan, begitu juga dengan tindak kejahatan anak oleh sebagian pakar hukum pidana Islam dikenakan hukuman ta'zir sekalipun kejahatan yang dilakukannya tersebut adalah kejahatan hudud.

Kesemua term di atas, apabila dilihat ke dalam al-Qur'an kita tidak akan menjumpai ayat yang memuat salah satu dari term tersebut secara eksplisit sehingga kasus kejahatan penyalahgunaan narkoba merupakan jenis jarimah ta'zir yaitu jenis kejahatan baru yang belum memiliki aturan-aturan yang tegas dan hukuman yang mendetail dalam al-Qur'an seperti jenis kejahatan hudud, qishash, dan kifarat sehingga sanksi hukuman kejahatan penyalahgunaan narkoba dihukum ta'zir yaitu diserahkan kepada pemerintah atau hakim yang menentukan hukumannya sesuai dengan berat dan ringannya tindak kejahatannya.Ketiadaan term narkotika, tidaklah membuat kejahatan narkotika luput dari kaca mata hukum Islam lewat qawa'id fikhiyah yaitu segala yang dapat memudharatkan atau merusakkan harus dihilangkan, maka secara kontekstual kaedah ini menunjukkan pelarangan atau haramnya atas segala tindakan yang dapat merusak kehidupan baik terhadap diri sendiri, orang lain, dan maupun lingkungan. Termasuk kasus penyalahgunaan narkotika yang menurut pakar dapat merusak pengguna atau pecandu narkoba dan apabila terus dibiarkan akan merusak generasi ke generasi yang lambat larut dapat mengancam nyawa insan manusia. Menurut ilmu kesehatan, pemakai candu

${ }^{23}$ Endang Jumali, "Penerapan Sanksi Pidana Ta'Zîr Bagi Pelaku Tindak Pidana Korupsi Di Indonesia," Asy-Syari'ah 16, no. 2 (31 Agustus 2014), https://doi.org/10.15575/as.v16i2.631. 
FITRAH Jurnal Kajian Ilmu-ilmu Keislaman

Vol. 04 No. 2 Desember 2018

secara psikis dapat membuat seseorang panthologis (ketergantungan) sehingga merasa tidak bisa hidup tanpa candu bahkan secara fisik dapat mengalami keracunan. Morphine juga sangat berbahaya bagi kehidupan insan manusia apabila disalahgunakan sebab pada mulanya obat ini dengan dosis kecil paling berguna di dunia kedokteran karena dapat menghilangkan rasa sakit menenangkan seluruh sistem urat syaraf namun apabila disalahgunakan dengan dosis yang besar dapat membuat seseorang mabuk dan tidak sadarkan diri.

Terlepas dari kasus narkotika, kita masuk ke kasus korupsi yang apabila ditelusuri ke dalam al-Qur'an tidak dijumpai term korupsi secara ekplisit namun esensi yang hampir mirip dengan term korupsi ada termasuk ghulul (penyelewengan kekuasaan) dan risywah (suap-menyuap), dimana al-Qur'an maupun sunnah tidak menguraikan hukuman yang detail mengenai pelakunya karena ayat maupun hadis yang berkaitan dengan kedua term tersebut lebih menekankan kepada hukuman akhirat dari pada hukuman duniawi sehingga dalam kajian hukum pidana Islam dijatuhi hukuman ta'zir yaitu diserahkan Allah SWT kepada pemerintah, pemimpin, atau hakim untuk menjatuhkan hukumannya.

Selanjutnya, peneliti beranjak dari kasus tipikor ke kasus tindak pidana kejahatan anak di bawah umur atau tentang hukuman terhadap anak-anak yang telah melakukan kejahatan yang merujuk kepada kitab Undang-undang Hukum Acara Pidana (KUHAP) warisan Belanda pada pasal 45 dinyatakan bahwa tindak pidana yang dilakukan orang dewasa sama dengan yang dilakukan oleh anak karena itu penyidikannya pun sama dengan penyidikan orang dewasa, maka di Indonesia dalam penegakkan hukum terhadap anak yang melakukan kejahatan terkadang mengabaikan batas usia anak sehingga tetap diproses walaupun belum cakap hukum, contoh kasus yang dialami Andang Pradika Poernama yang mendekam dalam tahanan Polisi selama 52 hari karena telah mengambil 2 ekor burung Leci milik tetangganya.

Berbeda dengan tindak kejahatan yang dilakukan oleh orang dewasa, maka menurut sebagian ulama dikenai hukuman ta'zir yaitu hukuman yang berupa pembelajaran agar tidak melakukannya lagi berupa teguran atau hukuman lainnya yang menurut hakim lebih cocok untuk diterapkan kepada pelaku, bahkan dalam Islam beban hukum diperuntukkan terhadap orang-orang yang sudah baligh (dewasa), waras, dan tidak dalam kondisi lupa sebagaimana 
tercantum dalam sebuah riwayat "Diangkat pena dari tiga golongan, anak-anak sampai baligh, orang gila sampai sembuh dan orang lupa sampai ingat". $\{H R$. Bukhari\}. Baligh atau dewasa yang dimaksud di sini, yaitu laki-laki sudah menjadi dewasa apabila sudah bermimpi yang mengakibatkan keluar mani sedangkan seorang perempuan menjadi dewasa apabila sudah haid. Dengan kata lain, bahwa kedewasaan seseorang dalam Islam lebih kepada kualitas bukan kuantitas umur seseorang yang dalam istilah ilmiahnya dewasa apabila sudah matang secara biologis bukan matang secara fisik. Terlepas dari persoalan batas umur anak, pidana bagi anak-anak yang bersalah dalam Islam dibebankan kepada walinya yaitu orang tuanya karena orang tua wajib mendidik anakanaknya agar menjadi orang baik sehingga apabila anak menjadi penjahat berarti orang tua tidak melaksanakan kewajibannya dengan baik maka orang tualah yang menanggung akibatnya diberikan sanksi karena kelaiannya.

\section{PENUTUP}

Banyak sistem hukum Indonesia, yang secara subtantif senada dengan sistem hukum pidana Islam termasuk tindakan penahanan yang dilakukan pihak kepolisian terhadap seorang yang diduga melakukan kejahatan guna untuk penyidikan,dimana tindakan penahanan semacam ini telah dipraktekkan Rasulullah SAW terhadap laki-laki yang diduga mencuri unta sampai terbukti bahwa yang bersangkutan terbukti tidak melakukan pencurian tersebut.

Begitu juga penerapan hukuman penjara di Indonesia, memiliki kesamaan dengan term hukuman ta'zir terlebih-lebih di zaman sekarang ini sebab penjara sudah menjadi kebutuhan mutlak dan bisa dikatakan bahwa sekarang ini tidak ada negara yang tidak punya lembaga pemasyarakatan termasuk negara-negara Islam di dunia termasuk Indonesia, maka sedikit atau banyak dan langsung atau tidak langsung memiliki kesamaan dengan praktek hukuman ta'zir penjara dalam sejarah Islam dan di nagara-negara Islam sekarang ini.

Penerapan hukuman di lapas kelas II B Padangsidimpuan, ketika dianalisis dari perspektif term hukuman ta'zir terdapat kesamaan yang cukup signikan terutama kasus-kasus yang berkaitan dengan jarimah ta'zir (kejahatan baru) seperti narkotikan dan tipikor, makasekalipun penerapan hukuman di lapas kelas II B Padangsidimpuan bedasarkan hukum positif Indonesia namun 
FITRAH Jurnal Kajian Ilmu-ilmu Keislaman

Vol. 04 No. 2 Desember 2018

secara langsung atau tidak langsung memiliki kesamaan dengan konsep hukuman ta'zir dalam hukum pidana Islan yang antara lain sebagai berikut :

1. Penetapkan hukuman di lapas kelas II B Padangsidimpuan, berdasarkan pertimbangan hakim sama dengan hukuman ta'zir yang juga berkaitan dengan pertibangan logika hakim dalam menjatuhkan hukuman ta'zir.

2. Penerapan hukuman di lapas kelas II B Padangsidimpuan, bertujuan menjaga ketertiban umum sama dengan tujuan penerapan hukuman ta'zir dalam kajian hukum pidana Islam. 


\section{DAFTAR PUSTAKA}

\section{BUKU}

A. DJazuli. Figh Jinayah; Upaya Menanggulangi Kejahatan dalam Islam. cet ke-3. Jakarta: Rajawali Pers, 2000.

Abd al-Qadir 'Audah. Al-Tasyri' al-Janaiy al-Islamy. Beirut: Muassasah al-Risalah, 1992.

Departemen Agama Republik Indonesia. Al-Qur'an Al-Karim dan Terjemahannya. Semarang: PT. Karya Toha Putra, 2002.

Hakim, Rahmat. Hukum Pidana Islam: Fiqh Jinayah. Bandung: Paustaka Setia, 2000.

Hanafi A., Asas-Asas Hukum Pidana Islam, Jakarta: Bulan Bintang, 1974.

Harahap, Zul Anwar Ajim. "Azas Legalitas dalam Hukum Pidana Islam." $A L-$ MAQASID: Jurnal Ilmu Kesyariahan dan Keperdataan 2, no. 1 (Juni 2016).

--------., Teori Hudud Muhammad Syahrur, Buletin Keadilan Fakultas Syariah dan Ilmu Hukum IAIN Padangsidimpuan, edisi II bulan April-Juni 2017.

-----------., Indonesia Nomor 36 Tahun 2009 Tentang Kesehatandan KUHP di Indonesia, Jurnal Al-Maqasid Fakultas Syariah dan Ilmu Hukum IAIN Padangsidimpuan,Volume 1 Nomor 2Juli 2015

Hasan, Abdul Halim, Tafsir ak-Ahkam, ed. Azhari Akmal Tarigan \& Agus Khair, Jakarta: Kencana, 2006

Jumali, Endang. "Penerapan Sanksi Pidana Ta'Zîr Bagi Pelaku Tindak Pidana Korupsi Di Indonesia." Asy-Syari'ah 16, no. 2 (31 Agustus 2014). https://doi.org/10.15575/as.v16i2.631.

Marsum, Jarimah Ta'zir; Perbuatan Dosa dalam Hukum Pidana Islam, Yogyakarta: Fakultas Hukum UII, 1988

Moeljatno. KUHP; Kitab Undang-Undang Hukum Pidana. edisi baru. Jakarta: PT. Bumi Aksara, 2008.

Munajat, Makhrus. Hukum Pidana Islam di Indonesia. Yogyakarta: Teras, 2009.

Muslich, H. Ahmad Wardi. Pengantar Dan Asas Hukum Pidana Islam: Fikih Jinayah. Jakarta: Sinar $\quad 2004$. https://books.google.co.id/books?id=rqedAQAACAAJ\&dq=Ahmad+Ward 
FITRAH Jurnal Kajian Ilmu-ilmu Keislaman

Vol. 04 No. 2 Desember 2018

i+Muslich,+Pengantar+dan+Asas+Hukum+Pidana+Islam;+Fiqh+Jinayah\& hl=en\&sa=X\&ved=0ahUKEwjJqK_3g87fAhUMknAKHVlADDwQ6AEIKT AA.

Pratiwi, Pengaruh Pembinaan Model Pesantren Terhadap Pembentukan Konsep Diri Warga Binaan Muslim di Lembaga Pemasyarakatan Kelas IIB Padangsidimpuan, Skripsi Mahasiswa Jurusan Bimbingan dan Konseling Islam Fakultas Dakwah dan Ilmu Komunikasi IAIN Padangsidimpuan Tahun 2016

Rokamah, Ridho. Al-Qawa'id Al-Fiqhiyah: Kaidah-Kaidah Mengembangkan Hukum Islam. Ponorogo: STAIN Ponorogo Press, 2007.

\section{WAWANCARA}

Wawancara dengan Eferida Harahap, S.H selaku Bendahara Pengeluaran Lembaga Pemasysrakatan Kelas II B Padangsidimpuan pada Kamis tanggal 21 Juni 2018.

Wawancara dengan ibu Efrida Sri Mulyana, S.H selaku Kasi Binadik/ Giatja Lembaga Pemasyarakatan Kelas II B Padangsidimpuan, pada hari Rabu tanggal 4 Juli 2018.

Wawancara dengan Bapak Ryan Ya'cub Azhari selaku anggota jaga Lembaga Pemasyarakatan Kelas II B Padangsidimpuan, pada hari Jum'at tanggal 20 Juli 2018.

Wawancara dengan Bapak Andika Pahlevi, S.H selaku Karupam Lembaga Pemasyarakatan Kelas II B Padangsidimpuan, pada hari Rabu tanggal 18 Juli 2018.

Wawancara dengan Bapak Drs. H. Asgul Dalimunthe, M.Si selaku BKM Mesjid Al-Ikhlas Lembaga Pemasyarakatan Kelas IIB Padangsidimpuan, pada hari Jum’at tanggal 20 Juli 2018.

Wawancara dengan Bapak Ali Basya, S.H selaku Kaur Kepegawaian \& Keuangan Lembaga Pemasyarakatan Kelas IIB Padangsidimpuan, pada hari Rabu tanggal 18 Juli 2018.

Wawancara dengan Bapak Muslihul Hayat Harahap, Amd., SE selaku Kasubsi Registrasi \& BimkemasLembaga Pemasyarakatan Kelas IIB Padangsidimpuan, pada hari Rabu tanggal 11 Juli 2018 